\title{
REDAKTIONELT FORORD
}

Dette temanummer af Tidsskriftet Antropologi handler om forholdet mellem etik og antropologi og om etiske problemstillinger i forskningen. Ambitionen har været at bringe artikler og positioner, der vil mere end bare pointere, at man bør behandle sine informanter ordentligt - hvad det så end indebærer - og i den forbindelse henvise til fagetiske retningslinjer for antropologens møde med felten og folk i felten.

Vores brede forståelse af antropologisk etik svarer til den tilgang, der præsenteres i antologien The Ethics of Anthropology (Caplan 2003a). I introduktionen konkluderer Pat Caplan for det første, at når vi som antropologer diskuterer etik, involverer det alle aspekter af faget: dets epistemologi, dets feltarbejdspraksisser og dets institutionelle og bredere sociale sammenhænge (Caplan 2003b:27). For det andet er det meget vanskeligt at skille etik fra politik og dermed også fra magtaspekter. Hvis man som Caplan ser tilbage på debatterne om etik og antropologi i de seneste fire årtier, er der tale om to konstant tilbagevendende temaer: relationerne mellem antropologen og „studiesubjekterne“ samt antropologens ansvar over for informanter og andre. Men disse temaer er aldrig rent interne anliggender, idet de snarere udspringer af de bredere sammenhænge, antropologien praktiseres i. Det betyder - stadig ifølge Caplan - at selv om vi ønsker at holde fast $\mathrm{i}$ visse moralske værdier såsom sandhed, integritet, empati og menneskelig værdighed, som vi er tilbøjelige til at forstå som tidløse og universelle, viser det sig, at etiske principper ændres over tid, og at forskellige principper får forskellig vægt afhængigt af den sammenhæng, de indgår i. For det tredje må enhver diskussion af etik nødvendigvis være refleksiv. For det fjerde må en antropologisk etik være kritisk, både over for os selv og vores fag. Og den må ikke være bleg for at stille de store spørgsmål: Hvad er antropologien god for? Hvem er den god for? Skal etik gentænkes for hver generation, i takt med at fagets grundlæggende betingelser ændres? Er der forskellige etikker for forskellige kontekster? 
Bidragene til dette temanummer spænder tilsvarende vidt. De rummer beskrivelser og analyser af etiske dilemmaer, loyalitetskonflikter, faglig refleksion, faglig selvforståelse og selvkritik, faglig formidling og repræsentation, etiske aspekter af fagligt og tværfagligt samarbejde og bud på en bred antropologisk etikforståelse. De fire artikler og otte positioner inden for temaet supplerer og kommenterer indirekte hinanden og lægger dermed op til diskussion.

\section{Litteratur}

Caplan, Pat (ed.)

2003a The Ethics of Anthropology: Debates and Dilemmas. London: Routledge. 2003b Introduction: Anthropology and Ethics. In: P. Caplan (ed.): The Ethics of Anthropology: Debates and Dilemmas. Pp. 1-33. London: Routledge. 